\title{
INDIA-MYANMAR RELATIONS: FROM IDEALPOLITIK TO REALPOLITIK
}

\author{
Azman Ayob
}

\section{ABSTRACT}

India's relations with Myanmar was generally cordial and close prior to 1960s. Myanmar Prime Minister U Nu believed it as 'firm IndoBurmese friendship.' This excellent bilateral relation between the two countries was generated by political and economic cooperation, plus good personal friendship between $U N u$ and Indian Prime Minister Jawaharlal Nehru. Although there were several hiccups along the relationship of the two countries in the 1960s and 1970s, but the bilateral relations was still good. However, after the failed 1988 major demonstration by the Burmese pro-democracy movement against the military rule, the bilateral relations of India and Myanmar was disrupted. India started to criticize strongly the new Burma's military junta - the State Law and Order Restoration Council (SLORC). India offered shelters for anti-SLORC dissidents and pro-democracy activists. India criticized strongly Myanmar's poor human rights record and advocated for Myanmar's return to democracy. India gave permission for Myanmar's opposition - the National Coalition Government of the Union of Burma (NCGUB) to open its office in New Delhi in 1992. During this time, it is clear that India's foreign policy towards Myanmar was to champion democratic ideals, urging and pushing Myanmar to return to democracy. Myanmar saw this as interference in its domestic affairs, but Myanmar lacked a trump card in forcing India to reconsider its stance, prompting Myanmar to turn to China for support. By 1993, India shifted its stance towards Myanmar from advocating democratic ideals to a more realistic policy based on India's national interests. This was due to at least five major factors, namely the China factor, the economic and strategic interests, and India's security problems in its Northeast region bordering Myanmar, Myanmar's image and international legitimacy, and India's ambition in Southeast Asia.

Keywords: democratic ideals, foreign policy, India, Myanmar, national interests 


\section{INTRODUCTION}

India and Myanmar are neighbours who share a land border for more than 1,600 kilometers, and Myanmar is the second largest neighbor of India. Apart from sharing territorial border, India and Myanmar also share maritime borders in the Bay of Bengal. Moreover, the people of India dwelling in India's Northeast region have ethnic connection across the border with border communities in Myanmar. Cross border trade and commerce between the two countries are in existence for centuries in history. ${ }^{1}$ Apart from geography, India and Myanmar are connected religiously. Myanmar is a country where Buddhism becomes the major belief among its people. India is a country where the founder of Buddhism was born. There exists a situation where Buddhists in Myanmar make religious pilgrimage to India. This religious-cultural exchange increases in the form of tourism to cities and places related to Buddhism in India, such as Bodhgaya, Sarnath and Sanchi. ${ }^{2}$

India and Myanmar also shared the same colonial master - the British. At one time in history the British ruled Myanmar from their base in India. Moments of independence of the two countries were also at about the same time. India gained its independence on $15^{\text {th }}$ August 1947 and approximately five months after that, on $4^{\text {th }}$ January 1948 Myanmar obtained its independence from the British. Among Southeast Asian countries, Myanmar was one of the earliest countries to obtain independence from the British, and attempted to play a significant role in this region. Myanmar's first democratically elected Prime Minister U Nu worked closely with the Indian Prime Minister Jawaharlal Nehru in an effort to unite Afro-Asian countries through the Bandung Conference in 1955. The conference was fruitful when two other similar conferences were held in Cairo 1957 and Belgrade in 1961. The conferences gave birth to the Non-Alignment Movement (NAM).

However, Myanmar as a new independent country did not enjoy an everlasting comfort of democracy. The democratic process in Myanmar was truncated by the military coup headed by General Ne Win in 1962. This military take-over marked the end of democracy in Myanmar. However, India still maintained its close relationship with Myanmar. The Indo-Burmese relations was good from 1962 to 1988, even though Myanmar adopted a close door policy politically and 
economically under the military leadership. ${ }^{3}$ The good Indo-Burmese relationship turned the other way round in 1988 after the infamous students' and peoples' demonstration against the military rule took place in the same year. India became Myanmar's staunch critic. India began to condemn Myanmar for violating human rights and democracy against its own people. India offered shelters for Myanmar's dissidents and pro-democracy activists and advocated for Myanmar's return to democracy. Due to this, India was seen by the Burmese people as giving a new hope for the return of democracy to their country. India also advocated for international community to isolate Myanmar. However, in early 1990s, India made a U-turn in its stance towards Myanmar's military junta. Through its policy of 'Look East' India became softer with Myanmar, advocating a more realistic policy based on India's own national interests. This turnaround policy is due to five major factors, namely the China factor, India's economic and strategic interests, India's security problems in its Northeast region bordering Myanmar, Myanmar's growing image and international legitimacy, and India's ambition in Southeast Asia.

\section{INDIA'S DEMOCRATIC AND HUMANIST REACTIONS, 1988-1993}

During this period of time, it was clear that India supported democratic ideals by becoming a staunch supporter of Aung San Suu Kyi. It was also clear that the Indian government under the leadership of Rajiv Gandhi at that time became the earliest Myanmar's neighbor to openly criticize the harsh policy of Myanmar military junta against the Burmese pro-democracy supporters after the 1988 demonstration. After that, Rajiv Gandhi government was not alone in this matter as the United States (U.S.) and the European Union (EU) joined together in criticizing Myanmar military government. For Aung San Suu Kyi and her party's followers, India under the leadership of Rajiv Gandhi became one of the movement's most active supporter. ${ }^{4}$

India also welcomed the anti-SLORC supporters and openly took side with Myanmar's pro-democracy activists. India's support for Aung San Suu Kyi was mainly based on the fact that she attended her high school in India in the 1960s where her mother was Myanmar ambassadress to New Delhi at that time, and her mother also had many good friends among the Indian politicians. ${ }^{5}$ India also 
opened its Northeast border and refugee camps were established for Burmese students and anti-SLORC pro-democracy supporters who fled Myanmar to avoid military retribution after the failed 1988 pro-democracy demonstration, such as in Mizoram, Manipur, Nagaland, Arunachal Pradesh, and Assam. ${ }^{6}$ The business of sheltering Myanmar's students and dissidents was not a new thing in IndiaMyanmar relations. It happened since General Ne Win took power through military means in 1962. Since then, India adopted an open door policy to Myanmar's students. This sort of policy was one of the many outcomes of the idealist-humanist and democratic concept found in Nehruvian diplomacy. The Indian Ministry of Foreign Affairs came out with the instruction that no genuine Myanmar's refugee who wanted to seek refuge in India be deported back to Myanmar. ${ }^{7}$

In 1991, Indian government set free Soe Myint, one of the former Burmese students of Rangoon University who hijacked a Thai Airways plane in its flight to Kolkata in November $1990 .{ }^{8}$ The objective of Soe Myint in the plane hijack incident was very clearly to gain international attention to the inhumanity of the Myanmar military junta when they refused to accept and acknowledge the election results in Myanmar in May 1990. With the help of some Indian politicians and non-governmental organizations (NGOs), Soe Myint and his friend were given the status of political refugee in India. This decision of the Indian government invoked a wrath from the Myanmar's military regime. To emphasize further the support for the pro-democracy activities and to criticize Myanmar under the military rule, in July 1992 the Indian government gave permission to Myanmar's military government opposition - the NCGUB to open its office in New Delhi. The Myanmar's SLORC government viewed this matter as a blatant interference in its domestic affairs. However, the Myanmar's military government was unable to pressure India to reconsider this permission. ${ }^{9}$

When India was under the leadership of Rajiv Gandhi, an organization - the India-Burma Friendship Society - was established. The members of this organization were Indian scholars and politicians. This organization supported all activities to reject the military dictatorship in Myanmar and also supported Burmese refugees. The first Chairman of this organization was K. R. Narayanan and his wife is a Burmese. Through this organization, some Indian politicians consistently gave support to efforts in isolating Myanmar's military 
junta from the international mainstream, and continuously criticized the Myanmar's SLORC government openly. ${ }^{10}$ Myanmar's military government officials were given cold reception in India. For example, in February 1992 the former Indian President R. Venkataraman gave a cold welcome to the new Myanmar ambassador in New Delhi and criticized the implementation of Myanmar's constitution. In August the same year, U Aye, the Director General of Myanmar Ministry of Foreign Affairs also was given a cold welcome in New Delhi when he was there to visit his officials. In November 1992, the Indian Minister of Water Resources made an open reiteration that the military generals in Yangon were a threat to the security of the region and India cannot remain idle in facing such dictatorial regime. ${ }^{11}$ The Indian government also gave permission for the establishment of Burmese Language Service in the All-India Radio (AIR) as an avenue for Myanmar's anti-SLORC supporters in India to garner international support. This AIR's Burmese Language Service became popular amongst Myanmar's military junta critics at the international level, and also had huge amount of listeners in Myanmar. ${ }^{12}$

Therefore, based on several above-mentioned facts, it was clear that India adopted a moralistic, idealist-humanist and democratic approaches in its relation with the military government of Myanmar between those periods of time. Moralistic politics and idealism became the nucleus in India-Myanmar bilateral relations.

\section{The Turnaround}

After 1990s approximately, India seemed to be having a moral fatigue. India could not manage to maintain the idealism of championing democracy for Myanmar. Efforts done by India in bringing back democracy in Myanmar and isolating its military junta at the international level were not successful. The tatmadaw generals in Yangon were not willing to compromise. India began to reconsider and eventually changed its foreign policy towards Myanmar form championing democratic idealism and humanism to a more pragmatic policy related closely to India's own national interests. For this reason, India toned down its critics on Myanmar's military junta and established cooperation with them in order to ensure India's new policy towards Myanmar become successful. In 1991 for example, following a pressure from Myanmar's military government, India 
barred the daughter of $\mathrm{U} \mathrm{Nu}$ - Than Than $\mathrm{Nu}$ from broadcasting through AIR's Burmese Language Service using abusive words in her critics against Myanmar military junta. In March 1993, India's Foreign Secretary, J. N. Dixit, visited Yangon where several major issues in the bilateral relations of the two countries were discussed. In the same year also, India sent trade delegation to Myanmar, and signed treaties of cooperation in eliminating cross border drugs trafficking activities between the two countries. In 1994, Indian army chief visited Myanmar and in the same year also preparations were made by the two countries to open Tamu-Moreh border passage from Manipur in India to Sagaing in Myanmar. ${ }^{13}$

Since 1993, India increased its economic assistance, foreign investment, and infrastructure projects in Myanmar. When India was under the Premiership of Narasimha Rao, the India's "Look East" policy was launched. Early short term target of this policy was to overcome threats and problems arising from the cross border terrorism and drugs smuggling between the two countries. Official high level visits between India and Myanmar became quite frequent. In November 2003, Indian Vice President, Bhairon Singh Shekhawat, visited Myanmar. In October 2004, Myanmar's President, Senior General Than Shwe, made his first six-day visit to India. New Delhi viewed this visit as historic due to the fact that it was Myanmar's first head of state-head of government high level visit in 24 years. During his visit, two memorandums of understanding (MOU) were signed, one on cultural exchange program 2004-2006 and another one was on Tamanthi hydroelectric project. India viewed its relations with Myanmar as friendly and has grown diversified in recent years, based on the mutual desire to establish long term cooperation between the two countries. ${ }^{14}$ In March 2006, Indian President, A. P. J. Abdul Kalam, visited Myanmar. ${ }^{15}$ Between 2000 and 2008, Myanmar's Senior General Maung Aye visited India three times. His first and second visits were in January and November 2000. The second visit was upon invitation by the Indian Vice President, Krishan Kant. The third visit of Maung Aye to India was in April 2008 and once again upon invitation by the Indian Vice President - Mohammad Hamid Ansari. Apart from Maung Aye's visit, there were two other visits by Myanmar's high officials in 2008 - in January was the visit by Myanmar Foreign Minister, Nyan Win, and in November was the visit paid by Myanmar's Prime Minister, Thein Sein. Myanmar's President, 
Senior General Than Shwe, once again visited India in July 2010 for a five-day visit. During his visit this time, six MOUs were signed. Agreement to increase cooperation between India and Myanmar was reached covering security, energy, oil and gas, infrastructure and agriculture. This visit also added its significance in India-Myanmar relations. Even though it was widely criticized by Western media, India stood firm with its 'Look East' policy, and viewed situations in Myanmar through realpolitik perspective. Because of national interests are more important, India no longer looked at Myanmar through Nehruvian's democratic idealist-humanist concept. ${ }^{16}$ Apart from political and diplomatic relations between India and Myanmar, military relations also seemed to be boosting between the two countries. In October 2010, Major General G. S. Malhi from the Indian Army's Higher Command Course visited Lieutenant General Hla Htay Win, Myanmar's Chief of Armed Forces Training in Naypidaw. During Malhi's five-day visit to Myanmar, he and his delegation visited Myanmar's National Defense College (NDC) and made known to his counterpart that Indian armed forces offered support to NDC and Staff College in Myanmar's armed forces. India is one of the world's countries where Myanmar armed forces send their officials for further studies, apart from China, Russia, Pakistan, Malaysia, and Singapore. Malhi also raised the issue of insurgency in India's Northeast region along the Indo-Burmese border when he met Myanmar's Northwest Regional Military Command chief, Brigadier General Soe Lwin, at his headquarters in Monywa, Sagaing Division. ${ }^{17}$

When the military government was replaced by the civilian government in Myanmar following the results of general election in November 2010, the Indo-Burmese relations seemed to be getting closer. In 2011, Indian Foreign Minister, S. M. Krishna, visited Myanmar to discuss about security and trade matters. New Delhi viewed this visit as an opportunity to bridging closer India's relations with the new Myanmar's civilian government. Krishna regarded his visit: ${ }^{18}$

[A]s an opportunity to further vitalize our multi-faceted relationship in the new political environment. We will have an exchange of views on enhancing security cooperation as well as our collaboration in the fields of connectivity, 
IT, energy, agriculture, power, telecommunications and infrastructure.

However, Krishna in his visit did not meet Myanmar's opposition and pro-democracy leader Aung San Suu Kyi, even though previously India was her staunch supporter. ${ }^{19}$ It was clear that India placed more weigh on good cooperation between the two countries rather than democracy in giving India's better benefits. Through this visit, India seemed to be committed in ensuring its success in economic commitment and strategic cooperation with the new Myanmar's civilian government. ${ }^{20}$ In October 2011, the President of the new Myanmar's civilian government - Thein Sein visited India together with a delegation comprised of more than twelve ministers and high officials. In this visit, he met with Indian Prime Minister - Manmohan Singh, and two MOUs were signed, in which one MOU was about the up gradation of Yangon Children's Hospital and Sittwe General Hospital, and the other MOU was on the Program of Cooperation in Science and Technology. In January 2012, Myanmar Foreign Minister, Wunna Maung Lwin, paid an official visit to India, where one of his activities during this visit was delivering a lecture on "Myanmar: A Country in Transition to Democracy" at the Indian Council for World Affairs. Indian Prime Minister Manmohan Singh also made an official visit to Myanmar in May 2012. He announced a few initiatives where twelve MOUs were signed between India and Myanmar, among others include the MOUs related to a new credit line for US\$500 million to Myanmar, Border Areas Development, and Air Service Agreement. ${ }^{21}$

The turnaround in India's foreign policy toward Myanmar is due to several factors that need India to strongly uphold its own national interests. The pragmatic reasons for India to change its policy towards Myanmar are, of course became clear.

\section{REASONS FOR THE PRAGMATIC TURNAROUND IN INDIA-MYANMAR RELATIONS}

As mentioned above, the major reason for India to change its foreign policy towards Myanmar from democratic idealist-humanist stance to realpolitik is because of India's own national interests. India finds itself at odds when geopolitical interests cross path with the support for democracy ${ }^{22}$, and of course India, like any other country will have 
to choose between the two notions - one is for survival and the other one is idealism. There exist a few factors concerning India's national interests, as explained below.

\section{The China Factor}

The Myanmar's military junta, with its bad record of human rights violation and oppression to the pro-democracy supporters after the 1988 uprising, became the target for international condemnation and isolation, even economic sanctions by the U.S. and the EU. The international condemn, economic sanction, and diplomatic isolation imposed on Myanmar gave opportunity to China, as Myanmar's comrade in arms, in getting closer to Myanmar. Since two decades ago, China developed a strong economic and military relationship with Myanmar. Trade agreements and deals were concluded between China and Myanmar in 1989 (worth US\$1.2 billion) and in 1994 (worth US\$400 million). These deals facilitated Myanmar's armed forces to modernize and upgrade their strength. China's military presence in Myanmar is viewed as a strategic threat to India and its national interests. The Chinese military presence in Myanmar alarmed India when Myanmar armed forces operated electronic surveillance with equipment acquired from China and the operation of this activity is done with the help of personnel from China's People's Liberation Army (PLA). This signal intelligence (SIGINT) equipment are installed along Myanmar's coastline and on a few offshore islands, such as Great and Little Coco Islands located less than 20 miles at the north of India's Andaman Island, and Ramree Island off the Rakhine coast. ${ }^{23}$ The purpose and functions of this SIGINT is to monitor military activities in the region, specifically air and naval movements in the Bay of Bengal. China also wanted to get access to the Bay of Bengal through Myanmar in order to get closer to its military ally who is also India's neighbor - Pakistan. ${ }^{24}$ The Chinese influence on Myanmar's military junta and China's presence in the Bay of Bengal displeased India and views it as a threat when China helped Myanmar to upgrade a few of its harbours and naval bases. According to Min Zin, China wanted to achieve world class blue-water navy status by 2050 , therefore making Myanmar as a 'springboard' for China to gain access to the Bay of Bengal in its long term two-ocean objective of direct access to the Pacific and the Indian Ocean. ${ }^{25}$ Apart from this, China also encourages Myanmar to have a close defence supply relations with Pakistan. ${ }^{26}$ This 
displeased India as Pakistan, one of India's most adjacent neighbours, is also India's arch enemy as both countries have fought in several wars, and still have a few unresolved security and military disputes.

Table 1: China's Arms Sales to Myanmar since $1989^{27}$

\begin{tabular}{|c|c|}
\hline Years & Materials \\
\hline 1989-1991 & $\begin{array}{l}3 \text { units JLG-43 Height finding radars; } 3 \text { units JLP-40 Air } \\
\text { surveillance radar; } 55 \text { units Type- } 63 \text { battle tanks; } 30 \text { units } \\
\text { WZ-121/Type- } 69 \text { battle tanks; } 100 \text { units YW-531H/Type- } 85 \\
\text { Armored personnel carriers; } 12 \text { units F-7M Air guard fighter } \\
\text { aircrafts; } 75 \text { units PL-2A Short range air-to-air missiles. }\end{array}$ \\
\hline $1992-1993$ & $\begin{array}{l}200 \text { units HN-5A Portable surface-to-air missiles; } 12 \text { units } \\
\text { F-6 Fighter aircrafts; } 10 \text { units Hainan/Type-037 Patrol } \\
\text { crafts; } 4 \text { units Type- } 311 \text { Fire control radars; } 50 \text { units Type- } \\
63 \text { Light battle tanks; } 30 \text { units Type- } 63 \text { 107mm Multiple } \\
\text { rocket launchers; } 24 \text { units Type- } 74 \text { 37mm Anti-aircraft guns; } \\
150 \text { units YW-531H/Type- } 85 \text { Armored personnel carriers; } \\
12 \text { units F-7M Air guard Fighter aircrafts; } 1 \text { unit JY-8A Fire } \\
\text { control radar. }\end{array}$ \\
\hline 1994-1997 & $\begin{array}{l}225 \text { units PL-2A Short range air-to-air missiles; } 4 \text { units Y-8 } \\
\text { Transport aircrafts; } 50 \text { units WZ-121/Type- } 69 \text { battle tanks; } \\
50 \text { units C-801/CSS-N-4/Sardine Anti-ship missiles; } 6 \text { units } \\
\text { Houxin/Type-037/1G Missile boats. }\end{array}$ \\
\hline 1998-1999 & $\begin{array}{l}24 \text { units A-5C Fantan fighter/ground attack aircrafts; } 12 \\
\text { units F-7M Air guard fighter aircrafts; } 40 \text { units PL-2A Short } \\
\text { range air-to-air missiles; } 40 \text { units PL-5B Short range air-to- } \\
\text { air missiles; } 5 \text { units Type-76 37mm Naval gun turrets; } 12 \\
\text { units K-8 Karakorum-8 Trainer/combat aircrafts. }\end{array}$ \\
\hline $2000-2007$ & $\begin{array}{l}3 \text { units Small armed warships; } 5 \text { units Rice Lamp fire } \\
\text { control radars; } 3 \text { units Type-344 Fire control radars; } 24 \text { units } \\
\text { C- } 801 / \text { CSS-N-4/Sardine Anti-ship missiles; } 8 \text { units AK-230 } \\
\text { 30mm Naval guns. }\end{array}$ \\
\hline
\end{tabular}

India, through its Foreign Minister, Krishna, during his visit to Naypidaw in 2011, raised its concern over Myanmar's growing dependence on China. This is partly due to the fact that Myanmar's President of the new civilian government - Thein Sein visited Beijing 
in May 2011, his first oversea visit since taking office. The purpose of Thein Sein visit was to discuss with the Chinese government conditions for the Chinese navy to base in Myanmar's seaports and secure direct access to the Bay of Bengal and the Indian Ocean. ${ }^{28}$ Realizing that there exists a threat when China uses certain facilities in Myanmar in widening its influence in the Indian Ocean, India feels the urgency to get closer to Myanmar in order to stop Myanmar from becoming China's proxy in disturbing India's national interests in the eastern flank and the Indian Ocean. If Myanmar becomes unfriendly to India, and hosting Chinese naval forces in its ports, it would be a grave security threat to India.

\section{India's Economic and Strategic Interests}

Another reason for India to change its foreign policy towards Myanmar is due to the importance of economic and strategic factor to India. The bilateral trade relations between India and Myanmar increased significantly from US\$12.4 million in 1980-1981 to US\$1070.88 million in 2010-2011. In 2006, India became Myanmar's fourth biggest trading partner after Thailand, China, and Singapore. India-Myanmar bilateral trade increased to US\$557.68 million in 2005-2006. In the same period of years, India's export to Myanmar stood at US\$38 million and US\$612 million. India's export to Myanmar is diversified, including pharmaceuticals, steel, electrical products and equipment. India also imported edible oil and wood, including wood products from Myanmar. ${ }^{29}$

From Myanmar's perspective, trading with India opened to huge economic advantages. From the result of good trade relations, Myanmar managed to join the Indian Initiatives for sub-regional economic and tourism integration - the Bangladesh, India, Sri Lanka and Thailand Economic Cooperation (BIMSTEC) in December 1997, and Mekong-Ganga Cooperation (MGC) in November 2000. ${ }^{30}$ In 2012, the total bilateral trade volume between India and Myanmar reached US\$1.87 billion ${ }^{31}$, and India stood as Myanmar's second largest major export partner in the same year. In June 2013, Indian Minister of Commerce and Industry, Anand Sharma, visited Naypidaw. He was met with Myanmar's Energy Minister, U Than Htay. In Sharma's three-day visit, India and Myanmar discussed on means and methods to 
improve economic cooperation in textile industries, infrastructure, oil and gas. Sharma also expressed the interest of Indian commercial banks in opening up their branches in Myanmar. Through Sharma also, New Delhi expressed its commitment and intention to deepening further cooperation in procuring energy, oil and natural gas from Myanmar. India and Myanmar also set a bilateral trade target between the two countries of US\$3 billion by the year $2015 .^{32}$

Table 2: India and Myanmar Bilateral Trade (in Million US\$) $)^{33}$ (Figures in brackets indicate variation from previous year(s))

\begin{tabular}{|l|l|l|l|l|l|}
\hline Years & $\mathbf{2 0 0 9 - 2 0 1 0}$ & $\mathbf{2 0 1 0 - 2 0 1 1}$ & $\mathbf{2 0 1 1 - 2 0 1 2}$ & $\begin{array}{l}\mathbf{2 0 1 2 -} \\
\mathbf{2 0 1 3}\end{array}$ & $\begin{array}{l}\mathbf{2 0 1 3 -} \\
\mathbf{2 0 1 4}\end{array}$ \\
\hline $\begin{array}{l}\text { India's exports } \\
\text { to Myanmar }\end{array}$ & $\begin{array}{l}207.97 \\
(6.17 \\
\text { percent })\end{array}$ & $\begin{array}{l}320.62 \\
(54.17 \%)\end{array}$ & $\begin{array}{l}545.38 \\
(70.1 \%)\end{array}$ & $\begin{array}{l}544.66 \\
(-0.13 \%)\end{array}$ & $\begin{array}{l}787.01 \\
(44.5 \%)\end{array}$ \\
\hline $\begin{array}{l}\text { India's imports } \\
\text { from Myanmar }\end{array}$ & $\begin{array}{l}1,289.80 \\
(38.84 \%)\end{array}$ & $\begin{array}{l}1,017.67 \\
(-21.1 \%)\end{array}$ & $\begin{array}{l}1,381.15 \\
(35.72 \%)\end{array}$ & $\begin{array}{l}1,412.69 \\
(2.28 \%)\end{array}$ & $\begin{array}{l}1395.67 \\
(-1.20 \%)\end{array}$ \\
\hline $\begin{array}{l}\text { TOTAL } \\
\text { TRADE }\end{array}$ & $\begin{array}{l}1,497.77 \\
(30.17 \%)\end{array}$ & $\begin{array}{l}1,338.29 \\
(-10.65 \%)\end{array}$ & $\begin{array}{l}1,870.20 \\
(39.75 \%)\end{array}$ & $\begin{array}{l}1,957.35 \\
(1.6 \%)\end{array}$ & $\begin{array}{l}2182.68 \\
(11.51)\end{array}$ \\
\hline
\end{tabular}

Besides trade, India becomes a huge foreign investor in Myanmar for the past several years. India invested in sectors such as agriculture, fisheries, mining, oil and gas, pearl cultivation, infrastructure, and tourism. In the oil and gas sector, India involves in a big natural gas project at Shwe in the Arakan state, which encompasses gas pipeline from Myanmar to India. There are two Indian companies involved in this project - the Oil and Natural Gas Company Videsh (ONGC) and Gas Authority of India (GAIL). This project will benefit India entirely, as India is in need of a long term energy deals with Myanmar, in which the security risks to the pipelines from Myanmar to India are low. ${ }^{34}$ As for Myanmar, this project is expected to give an average income of US\$580 million per year and in 20 years, Myanmar is expected to gain around US\$12 billion from this project. ${ }^{35}$ India also involves in a strategic venture in engaging Myanmar through the building of hydro-power project, the Tamanthi Dam Project. The MOU related to this project was signed between Myanmar's government and 
India's National Hydroelectric Power Corporation (NHPC) in 2004. The actual construction of Tamanthi Dam project in Chindwin River west of Sagaing Division was done in 2007. A second agreement concerning the dam project was signed in September 2008 to further strengthening the first agreement made in 2004 between India's NHPC and Myanmar's Department of Hydro Power Implementation (DHPI). The cost of the Tamanthi Dam Project is expected to be around US\$3 billion and India is expected to get 80 percent of electricity upon completion of the project. As for Myanmar, it is expected to be able to utilize electricity generated by the dam to generate the mining operation in Monywa. ${ }^{36}$ However, according to the former Indian Ambassador to Myanmar - V.S. Seshadri, the Tamanthi Dam Project has not proceeded smoothly as planned, even after Myanmar is now under the administration of a new civilian government. Red tape and bureaucratic hindrances at Myanmar's DHPI created a tension between India's NHPC and the officials of Myanmar's DHPI. If this massive dam project failed, it shall undermine India's 'Look East' policy in its effort to curtail China influence in Myanmar. ${ }^{37}$

Apart from the dam project, India involves in other investments in Myanmar. This include construction and upgrade of roads, railway lines, and bridges. India also involves in training Myanmar's skilled workers and human resource personnel. Many of these activities are the outcome of the agreements signed between India and Myanmar through many high level official visits between the two countries. ${ }^{38}$ In May 2012, for example, India's Tata Motors signed a distribution agreement for supplying passenger commercial vehicles in Myanmar with Apex Greatest Industrial Co. Ltd (AGI). The distribution of Tata vehicles, which will be assembled in Magwe, Myanmar will be done by AGI, apart from the distribution of imported cars from India. Both countries also achieved several agreements during the visit to Myanmar by the Indian Prime Minister Manmohan Singh in May 2012, which include among others, the upgrading of 17 bridges on the Tamu-Kalewa friendship road, operationalizing the Imphal-Mandalay bus service, and setting up an Advanced Centre for Agricultural Research and Education, in Myanmar. An agreement to increase air connectivity between India and Myanmar is also achieved during Manmohan Singh's visit where Myanmar's Airways International (MAI) will 
launch a direct flight route from Mandalay in Myanmar to Gaya in Bihar, India by November 2012. ${ }^{39}$

India also actively involves in military ties with Myanmar since the year 2000. Previously, India and Myanmar do not have strong military ties, apart from the event in 1949 when India provided arms and ammunition to Myanmar's U Nu government to suppress Karen rebellions. ${ }^{40}$ After this incident, there was no arms transfer from India to Myanmar. However, in its effort to get closer to Myanmar to counter China's influence as well as to gain Myanmar's support in eliminating and suppressing separatist groups such as United Liberation Front of Asom (ULFA) and United Nationalist Liberation Front (UNLF) who are making the thick jungle in Northwest Myanmar border as their bases in launching attacks on Indian territories, ${ }^{41}$ India strongly engages Myanmar in supplying military equipment. In 2003, India sold to Myanmar 80 units of $75 \mathrm{~mm}$ Howitzer, or better known as 'mountain gun,' and this matter was confirmed by the Indian Defense Ministry. ${ }^{42}$ In 2006, Indian Navy supplied two BN-2 Defender Islander maritime surveillance aircrafts and deck-based air defence guns. Other military equipment sold by India in 2006 and 2007 to Myanmar include 10 units of $105 \mathrm{~mm}$ light towed guns, 10 units mine protected vehicles, and 10 units T-55 tanks. ${ }^{43}$ In April 2007, it was reported that India and Myanmar top-notch military leaders met in New Delhi to negotiate the sale of additional military hardware to Myanmar. In the meeting, Myanmar's quartermaster general (who oversees all military supplies to Myanmar's armed forces), Lt. Gen. Tin Aung Myit Oo, asked for this military sale in return for Myanmar's assistance in suppressing Indian insurgents along the Indo-Burmese border. ${ }^{44}$ It was also reported that in mid of April 2008, India secretly transported trucks loaded with military equipment of artillery shells, bullets, and guns to Myanmar through border town of Moreh in India's Manipur (the Northeastern state). There are also critics hurled at India for supplying arms to Myanmar, condemning India as violating its democraticidealist principle, and as Myanmar's accomplice or partner in crime, for weapons supplied to Myanmar's armed forces, according to the critics, are mainly used to suppress Myanmar's internal rebellions of ethnic Kachin, Shan, and Karen. ${ }^{45}$ However, India is steadfast in its 'Look East' policy towards Myanmar in this matter. 
Table 3: Sales of India's Military Equipment to Myanmar since $\mathbf{2 0 0 3}^{46}$

\begin{tabular}{|l|l|}
\hline Year & Materials \\
\hline 2003 & 80 units $75 \mathrm{~mm}$ howitzers gun \\
\hline 2006 & $\begin{array}{l}2 \text { BN-2 Islander helicopters; } 10 \text { units 105mm light towed guns; } \\
10 \text { units mine protected vehicles }\end{array}$ \\
\hline 2007 & 10 units T-55 battle tanks \\
\hline 2008 & Artillery shells, bullets, and guns \\
\hline
\end{tabular}

\section{India's Security Problems in the Northeastern Region}

The situation in India's Northeast region bordering with Myanmar has long been a security problem to India. According to Jaswant Singh, the problem in Northeast India is endemic. It was present since before the arrival of the British. It is also the home-area of the Nagas, where since many decades ago, the dream of 'Greater Nagaland' is still appealing to them. ${ }^{47}$ This is one of the major reasons for India in changing its stance towards Myanmar. Rebels, as well as separatist groups such as National Socialist Council of Nagaland (NSCN), UNLF and ULFA are using the border areas of Myanmar's side as their bases in undermining India's security. Among these insurgent groups in the Indian Northeast region, NSCN is the most aggressive. In 1988, the NSCN was divided into two factions - the NSCN-Khaplang and the NSCN-Isak Muivah, making the Northeast Indian region bordering Myanmar full of violence and disturbances, largely fueled by weapons smuggling and drugs trafficking activities. For instance, ULFA killed 70 migrant workers from Bihar, India in January 2007 in its drive to flush out non-Assamese people from the region. In February the same year, the UNLF guerillas killed 24 Indian soldiers in two ambushes in Manipur. The then Indian Foreign Minister - Pranab Mukherjee upon returning from a visit to Myanmar in January 2007, said that: ${ }^{48}$

Our crackdown on the groups was never successful in the past - every time the guerillas fled across the border. It is impossible to crush these secessionist forces unless we get Burma's help and target them inside the forest there.

There also exists a relation between these Indian insurgent groups with Myanmar's ethnic armed groups in this region, especially with 
Kachin Independence Army (KIA) and Chin National Front (CNF). This relation becomes stronger with the fact that the leader of NSCN Khaplang is of Myanmar origin and the Naga people live in both sides of the India-Myanmar border. ${ }^{49}$

India strongly feels that it needs to foster a strong tie with Myanmar to curb these secessionist insurgencies. ${ }^{50}$ Military-to-military contacts between India and Myanmar increased since January 2000, starting from the official visit of Myanmar's Chief of Army Staff General Maung Aye to India. The armed forces of both countries began to increase their military offensive on the bases of the secessionist groups in the India-Myanmar border. In his official visit to India in October 2004, General Than Shwe gave his assurance to India that Myanmar armed forces shall conduct military operations against these rebel groups each winter, with material and intelligence support from India. ${ }^{51}$ Due to this assurance also, India started to offer Myanmar with whatever assistance it required, including arms supplies and development of infrastructure, in helping Myanmar to take action against these insurgent groups, ${ }^{52}$ as discussed earlier. However, India dissatisfied with the counterinsurgency operations effort taken by Myanmar against these separatist groups. According to the Indian Ministry of Defense, there is 'lack of progress in the Northeast' and this is not expected by India. ${ }^{53}$ According to Indian Home Minister at that time - Mullappally Ramachandran, the presence of India's separatist groups in Myanmar's territory is the most important security issue for India in each bilateral negotiation between India and Myanmar. However, despite Myanmar's assurance that no anti-India activities be allowed to carry on in its territory, the insurgent groups still almost freely use Myanmar's Northwest region as their safe sanctuary. ${ }^{54}$

Several incidents took place in this matter in which India is not happy. For example, Myanmar signed a ceasefire agreement in April 2012 giving autonomy to NSCN-Khaplang in three districts, namely Lahe, Leshi, and Nanyun in Myanmar's Sagaing Division without first informing and consulting India. Through this agreement also, the group is allowed to open a sub-office in Hkamti district, and members of NSCN-Khaplang are free to roam and move unarmed across the country. India has reiterated that it would not tolerate any cross border insurgency involving the NSCN-Khaplang. ${ }^{55}$ 


\section{Myanmar's Image and the Issue of International Legitimacy}

India maintains its pragmatic policy toward Myanmar, resulting more or less to an improved Myanmar's image and international legitimacy. In 2003, India defended Myanmar at the United Nations Commission on Human Rights, and Myanmar reciprocated this move of India by supporting India in its bid to be a permanent member of the UN Security Council, and giving assurance to India that any anti-India insurgent groups would not be allowed to stage chaos in Myanmar's territories. In 2004, in the official visit to India, General Than Shwe once again gave his commitment that Myanmar government was willing to work closely with India in preventing cross border crimes especially drugs trafficking and weapons smuggling, between the two countries. ${ }^{56}$

By becoming closer to India enables Myanmar to increase its catalogue of friends. India is no longer Myanmar's staunch critic of its poor record of human rights and democracy. To certain extent, the good relation with India has, more or less counter-balanced the Chinese's presence in Myanmar, and this boosted Myanmar government's image at the world's stage ${ }^{57}$ Myanmar also has been long trying to break the Chinese's economic domination, especially in its northern region where China's cheap products manufactured in Yunnan and Sichuan are dumped in Myanmar with cheap price, making Myanmar continuously dependence on products from China. ${ }^{58}$ With India as a friend, Myanmar managed to have a reconstruction, development, and economic progress. For example, between 1993-1994 and onwards, Myanmar's economic progress increased to 6 percent and its exports grew by 14 percent. In 2005-2010, India-Myanmar exports are valued between US\$341.40 million to US\$1010.56 million and imports between the two countries increase in the same period of years from US\$83.37 million to US\$194.03 million. Apart from this, ASEAN countries, South Korea and Japan are now heavily investing in Myanmar. ${ }^{59}$ Besides that, Myanmar also looked at India as a source of credit in providing Myanmar with means and tools to upgrade the country's outdated and poor infrastructure. For instance, India gave Myanmar US\$25 million credit in January 2003. 


\section{India's Ambition in Southeast Asia}

Myanmar bridges India with South Asia and Southeast Asia. Myanmar is also a member of Association of South East Asia Nations (ASEAN). Through its 'Look East' policy also, India aims to get closer to Southeast Asian countries, in order to benefit from their booming economies. India also plans to deter China from dominating this region. As Southeast Asia's region begins with Myanmar, India can not neglect Myanmar in its foreign diplomacy, if India wants to see its economic ambition in Southeast Asia successful. Actively engaging Myanmar is one of India's first moves to access Southeast Asia's markets. Among the first India's efforts towards this intention is to set up sub-regional forum in this region - the BIMSTEC and Mekong-Ganga Cooperation. Myanmar joined BIMSTEC six months after becoming member of ASEAN. The main objective of this sub-regional cooperation is to connect India with Southeast Asia, with infrastructure projects become the major activities, such as Trans-Asia Highway connecting India's Northeast region to Bangkok through Mandalay. ${ }^{60}$ India realizes that Myanmar could be a valuable connector between India and the northern countries of ASEAN, such as Thailand. This would enable India to open its Northeastern states for infrastructure and economic developments, in India's perhaps, a long-term move to overcome the problem of separatist groups in that region.

The inclusion of India as a dialogue partner of ASEAN in 1995 also can be seen as India's earlier move in getting closer with the Southeast Asian countries. This move is with the intention to further strengthening bilateral relations with a few ASEAN countries, such as Singapore. This island-state was instrumental in strongly supporting India's inclusion in dialogue partnership, membership of ASEAN Regional Forum (ARF), and ASEAN + 1 Summit meeting. ${ }^{61}$ From strategic point of view, with the deceased of the Cold War, it is quite irrefutable that India has become a new regional power, along with China. This notion is further strengthened by the fact that ASEAN countries look at India as having the capability to play a balancing role in this region. And regionally also, India's 'Look East' policy is accepted by ASEAN through its recognition by elevating India as ASEAN's Strategic Partner at the ASEAN-India Summit in New Delhi in December 2012. ${ }^{62}$ 


\section{CONCLUSION}

It is evident that the shift in India's foreign policy towards Myanmar since 1993 is fueled by the economic, security, and strategic interests. Myanmar, too is eager to deepen its bilateral relations with the two countries. India looks at its close economic relations with Myanmar as positive to the stability in the country. But, despite the fact that the close relations with India helps Myanmar to offset its dependence on China's support and assistance, India is still lagging behind in comparison with China's economic presence in Myanmar. ${ }^{63}$

A few points need to be given attention in improving the bilateral relations of India and Myanmar. India is seen by Myanmar as not having enough commitment and bureaucratic will. Myanmar sees India as not acting fast in upgrading India-Myanmar ties, even though India has cultural and historical linkages with Myanmar, an advantage that China does not have. The Burmese think that they are closer to India rather than to China. India should look at this perspective as its own advantage in fostering further the Indo-Burmese relations.

India has an aspiration to be a regional power. But India is not aggressive enough to lend its economic aids and assistance to Myanmar. Currently, Myanmar is facing some domestic problems, such as ethnic conflict. India should realize that a developed and prosperous region could not be created when countries in that region, such as Myanmar are engulfed by domestic security problem. Even though globally India is seen as the rising economic power in the region, but it could not give any meaning when the region itself is laden with many security issues. India should be more robust in helping Myanmar to curb its security problem in order to reap maximum economic benefits that Myanmar can offer in the bilateral relations of the two countries.

India also needs to widen its foreign policy towards Myanmar beyond security and natural resources. India should engage Myanmar in many more areas. ${ }^{64} \mathrm{In}$ light of this suggestion, India could bring back its Nehruvian idealism in its Myanmar's policy, of course step by step, as Myanmar is now slowly becoming democratic under the leadership of former President Thein Sein and newly elected President Htin Kyaw, as India had shown its democratic-idealist-humanist reactions in supporting democracy after the 1988 uprising in Myanmar, India 
could now do again the same effort through its close relations with Myanmar. There is a suggestion that India should not remain on the sidelines without playing a more important and constructive role in Myanmar, it might usher in Western influence into its own backyard. ${ }^{65}$ Democracy embraces Myanmar once again, and India should not 'stand idle with folding arm' by becoming indifference to the recent wind of change in Myanmar.

\section{NOTES}

1 Qasim Ahmad, "India-Myanmar Relations: Delhi on the Wrong Side of History," Paper Presented at the Fifth GCA Conference, 18-20 October 2011, Kuala Lumpur, pp. 1-18.

2 Renaud Egreteau, Wooing the Generals: India 's New Burma Policy, New Delhi: Authorpress, 2003, p. 112.

3 Jatswan S. Sidhu, "India's Myanmar Policy Since 1988: Between Democratic Ideals and Geostrategic Imperatives," Journal of International Studies, Vol. 5, 2009, pp. 93-94.

4 See Ahmad, "India-Myanmar Relations," p. 5; and Jan Cartwright, "India's Regional and International Support for Democracy: Rhetoric or Reality?," Asian Survey, Vol. 49, No. 3, 2009, pp. 413-414.

5 Jurgen Haacke, Myanmar's Foreign Policy: Domestic Influences and International Implications, Adelphi Paper No. 381, London: Routledge, 2006, p. 34.

6 Egreteau, Wooing the Generals, p. 121; and Jatswan S. Sidhu, "India's Myanmar Policy," p. 97.

7 Egreteau, Wooing the Generals, p. 122.

8 Haacke, Myanmar's Foreign Policy, p. 34.

9 Ibid.

10 Egreteau, Wooing the Generals, p. 124.

11 Ibid., pp. 124-125.

12 Sidhu, "India's Myanmar Policy," p. 97.

13 Ibid., p. 99.

14 “Than makes 'historic' visit," The Times of India, 25 October 2004, $<$ http://articles.timesofindia.indiatimes.com/2004-10-25/india/27151965_1_ tamanthi-myanmar-senior-general>

15 Sidhu, “India’s Myanmar Policy,” pp. 99-100. 
16 Balaji Chandramohan, "India embraces Myanmar's Military junta on terms of Realpolitik," World Security Network, 29 July 2010, <http:// www.worldsecuritynetwork.com/Asia-India/balaji-chandramohan-/India'sembraces-Myanmar's-military-junta-on-terms-of-Realpolitik>

17 Wai Moe, "Indian Military Delegation Visits Burma," The Irrawaddy, 2 November 2010, <http://www2.irrawaddy.org/article.php?art_id=19920> 18 "Krishna reaches Myanmar; trade, security relations on agenda," The Hindu, 20 June 2011, <http://www.thehindu.com/news/national/krishnareaches-myanmar-trade-security-relations-on-agenda/article2120580.ece> 19 Daniel Schearf, "India Puts Security, Trade With Burma Ahead of Democracy," Voice of America News, 20 June 2011, <http://www. voanews.com/content/india-puts-security-trade-with-burma-ahead-ofdemocracy-124279464/141092.html>

20 Nirmala George, "India, Burma to Discuss Trade and Security Ties," The Irrawaddy, 21 June 2011, <http://www2.irrawaddy.org/article.php?art_ $\mathrm{id}=21533>$

21 India-Myanmar Relations, New Delhi” Ministry of External Affairs (MEA), India, 2014, <http://meaindia.nic.in/meaxpsite/foreignrelation/ myanmar.pdf $>$

22 Cartwright, "India's Regional and International Support for Democracy," pp. 405-406.

23 Sidhu, "India's Myanmar Policy," p. 100; Renaud Egreteau, "India's Ambitions in Burma: More Frustration than Success?" Asian Survey, Vol. 48, No. 6, 2008, p. 944; and Andrew Selth, "Burma's China Connection: Implications for India," in P. V. Rao (ed.), India and ASEAN: Partners at Summit, Hyderabad: Centre for Indian Ocean Studies, Osmania University, 2011, p. 368.

24 Renaud Egreteau, "India-Myanmar Relations: Courting the Junta?," in Rao (ed.), India and ASEAN, pp. 358-359.

25 Min Zin, "China-Burma Relations: China's Risk, Burma's Dilemma," in Lowell Dittmer (ed.), Burma or Myanmar? The Struggle for National Identity, Singapore: World Scientific Publishing, 2010, p. 278.

26 Poon Kim Shee, "The Political Economy of China-Myanmar Relations: Strategic and Economic Dimensions," Ritsumeikan Annual Review of International Studies, Vol. 1, 2002, pp. 33-53.

27 "SPDC Arms Suppliers," Alternative Asean Network on Burma, <http:// www.altsean.org/Research/SPDC\%20Whos\%20Who/Armssuppliers. htm\#India> 
28 Sai Zom Hseng, "New Delhi Raises Security Issue with Naypidaw," The Irrawaddy, 22 June 2011, <http://www2.irrawaddy.org/article.php?art_ $\mathrm{id}=21546>$

29 Sidhu, “India’s Myanmar Policy,” p. 100.

30 Haacke, Myanmar's Foreign Policy, p. 35; and India-Myanmar Relations - MEA.

31 "India, Myanmar set bilateral trade target of $\$ 3$ bn by 2015," Zee News, $<$ http://zeenews.india.com/business/news/economy/india-myanmar-setbilateral-trade-target-of-3-bn-by-2015_77559.html>

32 Ibid.

33 "Bilateral \& Economic Relations," Yangon: Embassy of India, Myanmar, $<$ http://www.indiaembassyyangon.net/index.php?option=com_content\&vie $\mathrm{w}=$ category\&layout=blog\&id=21\&Itemid=122\&lang=en $>$

34 Cartwright, "India's Regional and International Support for Democracy," p. 415.

35 "Burma-India relations: A betrayal of democracy and human rights," Burma Campaign UK - A summary of the key issues relating to Burma and India, March 2007, <http://www.burmacampaign.org.uk/reports/ India_Briefing.pdf $>$

36 “India-Burma Relations," Arakan Rivers Network, 2009, <http:// arakanrivers.net/?page_id=147>

37 Shivananda H., "Tamanthi Hydel Profect: India's Eastern Foothold," IDSA Comment, 6 June 2011, New Delhi: Institute for Defence Studies and Analyses, <http://www.idsa.in/idsacomments/TamanthiHydelProject\%3AI ndiasEasternFoothold_shivananda_060611>

38 See India-Myanmar Relations - MEA.

39 C. S. Kuppuswamy, "India-Myanmar Relations - An Update," South Asia Analysis Group, Paper No. 5334, 21 December 2012, <http://www. southasiaanalysis.org/node/1099>

40 Thin Thin Aung and Soe Myint, "India-Burma relations," Online Myanmar/Burma Library, <http://burmalibrary.org/docs3/challenges_to democratization_in_burma-Chapter 4.pdf $>$

41 "India begins supplying Myanmar military hardware - Rahul Bedi," BurmaNet News, 4 October 2006, <http://burmanet.org/news/2006/10/04/ ians-india-begins-supplying-myanmar-military-hardware-rahul-bedi/>

42 William Ashton, "The arms keep coming - but who pays?," The Irrawaddy, 15 July 2004, < http://burmanet.org/news/2004/07/15/irrawaddythe-arms-keep-coming-who-pays-william-ashton/> 
43 "SPDC Arms Suppliers."

44 "Burma to Buy More Indian Weapons," The Irrawaddy, 24 April 2007, $<$ http://www2.irrawaddy.org/article.php?art_id=7046>

45 Nirmala Carvalho, "By arming Burmese military India 'complicit' in violence," Asia News, 9 July 2011, <http://www.asianews.it/news-en/Byarming-Burmese-military-India-complicit-in-violence-22141.html>

46 "SPDC Arms Suppliers."

47 Jaswant Singh, "Assam's Crisis of Citizenship: An Examination of Political Errors," Asian Survey, Vol. 24, No. 10, 1984, pp. 1057.

48 "India seen arming Burma to counter Chinese," The Washington Times, 23 March 2007, <http://www.washingtontimes.com/news/2007/ mar/23/20070323-103215-4113r/?page $=$ all $>$

49 Egreteau, "India-Myanmar Relations," p. 357.

50 Sidhu, "India's Myanmar Policy," p. 101.

51 Egreteau, "India's Ambitions in Burma," p. 945.

52 "India seen arming Burma to counter Chinese," The Washington Times.

53 Egreteau, "India's Ambitions in Burma," p. 946.

54 "Northeast insurgents using Myanmar as safe sanctuary," Rediff News, 28 August 2012, <http://www.rediff.com/news/report/northeast-insurgentsusing-myanmar-as-safe-sanctuary/20120828.htm>

55 Rahul Mishra, "Why India is wary of Myanmar-NSCN-K agreement," RediffNews, 24 May 2012, <http://www.rediff.com/news/column/why-indiais-wary-of-myanmar-nscn-k-agreement/20120524.htm>

56 Haacke, Myanmar's Foreign Policy, p. 37.

57 Sidhu, "India's Myanmar Policy," p. 102.

58 Egreteau, Wooing the Generals, pp. 82-83; and Swaran Singh, "The China Factor in India's Look East Policy," in Rao (ed.), India and ASEAN, p. 250.

59 Subhash Kapila, "India-Myanmar Strategic Partnership: Indian Imperatives," South Asia Analysis Group, Paper No. 197, 2012, <http:// southasiaanalysis.org/paper197>

60 Egreteau, "India-Myanmar Relations: Courting the Junta?" pp. 359-360.

61 G. V. C. Naidu, "India and Southeast Asia: An Analysis of the Look East Policy," in Rao (ed.), India and ASEAN, p. 141.

62 Subhash Kapila, "India's Look East Policy, Act East and South China Sea: Politico-Strategic Dynamics," South Asia Analysis Group, Paper No. 5603, 2013, <http://southasiaanalysis.org/node/1404> 
63 Haacke, Myanmar's Foreign Policy, p. 38.

64 Sidhu, "India's Myanmar Policy," p. 104.

65 R. Hariharan, "Taking A Re-Look At India-Myanmar Relations," South Asia Analysis Group, Paper No. 1141, 2004, <http://www.southasiaanalysis. org/paper1141> 